\title{
HUBUNGAN DUKUNGAN SOSIAL TERHADAP KEMAMPUAN SOSIALISASI ANAK BERKEBUTUHAN KHUSUS : STUDI META ANALISIS
}

\author{
Seno \\ Program Pasca Sarjana Pendidikan Anak Usia Dini, Universitas Negeri Semarang \\ e-mail : cahpengging@gmail.com
}

\begin{abstract}
This study aims to determine the relationship between social support and the ability to socialize children with special needs (ABK). The relationship / influence will be carefully examined by the results of previous studies. This research uses a meta-analysis method. Meta analysis is the study of a number of research results in a similar problem. The unit of analysis in this study is written documents about the relationship of social support to the ability of ABK socialization in the form of journal articles and research reports taken by purposive sampling based on their compatibility with the research theme. The main instrument of this study is the researchers themselves assisted with documentation guidance. Analysis of the data used is the analysis of quantitative data with percentages and analysis of qualitative data for the data of the results of the narrative study of the researches that were found. The results showed that social support from both the family and the teacher could have a positive effect on the socialization ability of children with special needs.

Keywords: Meta Analysis, Social support, Ability to socialize, ABK
\end{abstract}

\begin{abstract}
Abstrak
Penelitian ini bertujuan untuk mengetahui hubungan antara dukungan sosial terhadap kemampuan sosialisasi anak berkebutuhan khusus (ABK). Hubungan/ pengaruh tersebut akan penulis teliti dari hasil-hasil penelitian terdahulu. Penelitian ini menggunakan metode meta-analisis. Meta analisis merupakan kajian atas sejumlah hasil penelitian dalam masalah yang sejenis. Unit analisis dalam penelitian adalah dokumen-dokumen tertulis tentang penelitian hubungan dukungan sosial terhadap kemampaun sosialisasi ABK yang berupa artikel jurnal dan laporan penelitian yang diambil secara Purposive sampling berdasarkan kesesuaiannya dengan tema penelitian. Instrumen utama penelitian ini ada peneliti sendiri dibantu dengan panduan dokumentasi. Analisis data yang digunakan adalah analisis data kuantitatif dengan prosentase dan analisis data kualitatif untuk datadata hasil kajian naratif terhadap penelitian-penelitian yang ditemui. Hasil penelitian menunjukkan bahwa dukungan sosial baik itu dari keluarga maupun guru dapat berpengaruh positif terhadap kemampuan sosialisasi anak berkebutuhan khusus.
\end{abstract}

Kata Kunci: Meta Analisis, Dukungan sosial, Kemampuan sosialisasi, ABK

\section{PENDAHULUAN}

Anak berkebutuhan khusus sering kali mengalami berbagai persoalan psikologis yang timbul akibat kelainan bawaan dirinya maupun akibat respons lingkungan terhadap ketunaan yang dialami anak tersebut.Dukungan dari lingkungan social (dukungan social) bagi anak berkebutuhan khusus sangat mempengaruhi perkembangan anak tersebut (Efendi, 2008). Dalam kenyataannya, anak berkebutuhan khusus yang memperoleh dukungan social yang baik dari lingkungannya mampu menunjukkan prestasi tak kalah gemilang baik dalam bidang pendidikan formal maupun ketrampilan sehingga anak tersebut mampu mandiri dalam kehidupannya(Walinono, 1999). Di sisi lain anak-anak usia sekolah yang secara fisik maupun mental normal meskipun memperoleh dukungan social yang baik daril ingkungan beberapa anak menunjukkan prestasi dan sebagian lainnya menunjukkan perilaku negative.

Berdasarkan fenomena inilah penulis merasa sangat tertarik untuk mengkaji secara lebih terfokus, berkaitan dengan hal dukungan social yang mempengaruhi kemampuan sosialisasi dan ingin mengetahui apakah ada perbedaan kemampuan social yang ditampilkan si anak berkebutuhan khusus dengan anak yang normal, tentu saja dengan variasi dukungan social yang diperoleh kedua anak tersebut. Fenomena anak berkebutuhan khusus dengan latarbelakang dukungan social yang variatif, sebagian menunjukkan prestasi anak yang gemilang, sementara di sisi lainnya pada anak normal dengan latarbelakang dukungan social yang variatif sebagian menunjukkan prestasi yang gemilang pula dan sebagian lainnya tidak demikian, Dengan metode meta analisis penulis ingin memastikan apakah dukungan sosial dapat 
mempengaruhi kemampuan sosialisasi anak berkebutuhan khusus?

\section{KAJIAN PUSTAKA}

\section{Dukungan Sosial}

Dukungan sosial didefinisikan sebagai dukungan yang terdiri atas enam kategori: kelekatan, integrasi sosial, kesempatan untuk membantu, pengakuan yang positif, ketergantungan yang dapat diandalkan, dan memperoleh informasi dan bimbingan dalam keadaan stres dan depresi (Weiss, 1974 dalam Mahon, dkk., 2004: 217). Dukungan sosial merupakan semua bentuk dukungan spiritual dan finansial yang diterima seorang individu dari individu lain yang berada disekitarnya terutama bagi individu yang mempunyai hubungan dekat.

Dukungan sosial juga diartikan sebagai dukungan atau bantuan yang dibutuhkan oleh individu dan bisa didapatkan dari berbagai sumber seperti keluarga, teman, dokter atau profesional dan organisasi kemasyarakatan. Dukungan sosial juga didefinisikan sebagai keberadaan orang lain yang dapat diandalkan untuk memberi bantuan, semangat, penerimaan dan perhatian, sehingga bisa meningkatkan kesejahteraan hidup bagi individu yang bersangkutan (Saputri \& Indrawati, 2013).

Dukungan sosial merupakan semua bentuk dukungan spiritual dan finansial yang diterima seorang individu dari individu lain yang berada disekitarnya terutama bagi individu yang mempunyai hubungan dekat. Dukungan sosial dapat diberikan berupa informasi, nasehat, bantuan nyata atau suatu tindakan yang diberikan oleh suatu jaringan sosial yang akrab atau didapat karena kehadiran jaringan sosial tersebut dan mempunyai manfaat emosional atau manfaat perilaku. Secara teoritis adanya dukungan sosial dapat menurunkan kecenderungan munculnya kejadian yang dapat mengakibatkan stress dan pemberian dukungan ini diperoleh dari hubungan sosial yang akrab,yang membuat individu merasa diperhatikan,bernilai dan dicintai. Sehingga dengan adanya dukungan sosial, dapat menguntungkan bagi individu yang menerimanya, (Cobb, 2011).

Menurut Cutrona dan Gardner, (2004), dalam Sarafino, (2011), terdapat empat bentuk dukungan sosial yaitu:

1. Dukungan emosional.
Dukungan ini dapat berupa ungkapan empati, simpati, kasih saying kepedulian seseorang terhadap yang lain, contohnya guru terhadap muridnya, terapis terhadap kliennya.

2. Dukungan penghargaan.

Dukungan penghargaan adalah suatu bentuk dukungan yang berupa ungkapan yang di berikan oleh orangtua, guru bahkan orang orang disekelilingnya dalam hal membantu anak membangun kompetensi dan mengembangkan harga diri anak. Pemberian dukungan ini dapat juga membantu individu untuk melihat segi-segi positve yang ada dalam dirinya dibandingkan dengan keadaan orang lain yang berfungsi sebagai pembentukan rasa kepercayaan diri dan kemampuan serta merasa dihargai dan bisa berguna saat individu tersebut dalam tekanan atau masalah.

\section{Dukungan instrumental.}

Dukungan instrumental adalah bentuk dukungan yang berupa material dan lebih bersifat bantuan, sumbangan dana, uang dan lain sebagainya.

\section{Dukungan informasi.}

Suatu bentuk dukungan yang lebih bersifat nasihat, memberitahukan hal yang baik, terhadap apa yang sudah dilakukan individu tersebut.

\section{Interaksi Sosial}

Interaksi sosial merupakan suatau hubungan antara individu satu dengan individu lainnya dimana individu yang satu dapat mempengaruhi individu yang lainnya sehingga terdapat hubungan yang saling timbal balik menurut Bimo Walgito (1990 dalam Dayakisni, 2009). Sementara Soekanto (1997 dalam Dayakisni, 2009) mendefinisikan interaksi sosial sebagai hubungan antar orang per orang atau dengan kelompok manusia. Interaksi sosial tak akan mungkin terjadi apabila tidak memenuhi dua syarat, yaitu 1) adanya kontak sosial, dan 2) adanya komunikasi. Kontak sosial dapat terjadi antara individu dengan individu, antara individu dengan kelompok, dan antara kelompok dengan kelompok. Sementara komunikasi baik verbal ataupun nonverbal merupakan saluran untuk menyampaikan perasaan ataupun ide/pikiran dan sekaligus sebagai media untuk dapat menafsirkan atau memahami pikiran atau perasaan orang lain.

Bentuk- bentuk interaksi sosial adalah Asosiatif dan Disasosiatif

a. Asosiatif 
Asosiatif terdiri dari kerjasama (cooperation), akomodasi (accomodation). Kerjasama disini dimaksudkan sebagai suatu usaha bersama antara orang perorangan atau kelompok manusia untuk mencapai satu atau beberapa tujuan bersama. Akomodasi merupakan suatu cara untuk menyelesaikan pertentangan tanpa menghancurkan pihak lawan sehingga lawan tidak kehilangan kepribadiannya.

\section{b. Disasosiatif}

Disasosiatif terdiri dari persaingan (competition), dan kontravensi (contravention), dan pertentangan (conflict). Persaingan diartikan sebagai suatu proses sosial di mana individu atau kelompok-kelompok manusia yang bersaing mencari keuntungan melalui bidang-bidang kehidupan yang pada suatu masa tertentu menjadi pusat perhatian umum (baik perseorangan maupun kelompok manusia) dengan cara menarik perhatian publik atau dengan mempertajam prasangka yang telah ada tanpa mempergunakan ancaman atau kekerasan. Kontravensi merupakan sikap mental yang tersembunyi terhadap orang- orang lain atau terhadap unsur-unsur kebudayaan suatu golongan tertentu. Pertentangan merupakan suatu proses sosial dimana individu atau kelompok berusaha untuk memenuhi tujuannya dengan jalan menantang pihak lawan yang sering disertai dengan ancaman dan/atau kekerasan.

\section{Anak Berkebutuhan Khusus}

Anak Berkebutuhan Khusus adalah anak yang mengalami pertumbuhan dan perkembangan menyimpang dari kriteria normal baik secara fisik, psikis, emosi dan perilaku (Poerwanti, 2007).

Anak berkebutuhan khusus atau yang pada masa lampau disebut anak cacat memiliki karakteristik khusus dan kemampuan yang berbeda dengan anak-anak pada umumnya. Tipe anak berkebutuhan khusus bermacam-macam dengan penyebutan yang sesuai dengan bagian diri anak yang mengalami hambatan baik telah ada sejak lahir maupun karena kegagalan atau kecelakaan pada masa tumbuh-kembangnya. Menurut Kauffman \& Hallahan (2005) dalam Bendi Delphie (2006) tipe-tipe kebutuhan khusus yang selama ini menyita perhatian orangtua dan guru adalah (1) tunagrahita (mental retardation) atau anak dengan hambatan perkembangan (child with development impairment), (2) kesulitan Belajar (learning disabilities) atau anak yang berprestasi rendah, (3) hiperaktif (Attention Deficit Disorder with Hyperactive ), (4) tunalaras (Emotional and behavioral disorder), (5) tunarungu wicara (communication disorder and deafness), (6) tunanetra atau anak dengan hambatan penglihatan (Partially seing and legally blind), (7) autistik, (8) tunadaksa (physical handicapped), dan (9) anak berbakat (giftedness and special talents).

\section{METODE PENELITIAN}

Desain : Penelitian ini merupakan studi metaanalisis terhadap sejumlah studi primer yang pernah dilakukan untuk menguji terhadap hubungan antara dukungan sosial dengan kemampuan sosialisasi pada anak berkebutuhan khusus.

Sumber data : Sampel penelitian ini menggunakan teknik Purposive Sampling. Data atau informasi yang diperoleh dari sampel ditentukan berdasarkan tema-tema penelitian yang sesuai. Dalam penelitian ini ada enam artikel, baik yang telah dipublikasikan melalui jurnal ilmiah maupun hasil penelitian yang dipublikasikan melalui internet dari tahun 2015 hingga 2019. Data diperoleh dari sejumlah artikel yang didapatkan melalui database di Internet, yang ditelusuri melalui google schoolar. Kata kunci yang digunakan untuk pencarian adalah dukungan sosial, kemampuan sosialisasi, anak berkbutuhan khusus.

Tabel 1. Sumber data penelitian

\begin{tabular}{c|l|l|c|l|c}
\hline $\begin{array}{c}\text { N } \\
\text { o }\end{array}$ & \multicolumn{1}{|c|}{ Peneliti } & \multicolumn{1}{|c|}{ Judul } & $\begin{array}{c}\text { Tahu } \\
\mathbf{n}\end{array}$ & Variabel & Tempat \\
\hline 1 & Desiyani Nani, & $\begin{array}{l}\text { Pengaruh Dukungan Sosial } \\
\text { Terhadap Kemampuan }\end{array}$ & 2018 & $\begin{array}{l}\text { Dukungan } \\
\text { sosial dan } \\
\text { kemampuan } \\
\text { sosialisasi }\end{array}$ & $\begin{array}{c}\text { Purwokert } \\
\text { Oahyu }\end{array}$ \\
& $\begin{array}{l}\text { Ekowati, Ryan } \\
\text { Sosisalisasi anak } \\
\text { berkebutuhan khusus }\end{array}$ & & $\begin{array}{l}\text { Dukungan } \\
\text { keluarga dan }\end{array}$ & $\begin{array}{c}\text { Yogyakart } \\
\text { a }\end{array}$ \\
\hline 2. & $\begin{array}{l}\text { Redi Iriawan, } \\
\text { Nubungan dukungan keluarga } \\
\text { dengan kemampuan }\end{array}$ & 2015 & & \\
\hline
\end{tabular}




\begin{tabular}{|c|c|c|c|c|c|}
\hline & $\begin{array}{l}\text { Aris Budi } \\
\text { Pratama }\end{array}$ & $\begin{array}{l}\text { sosialisasi anak retardasi } \\
\text { mental ringan di slbn } 1 \text { bantul } \\
\text { yogyakarta } 2015\end{array}$ & & $\begin{array}{l}\text { kemampuan } \\
\text { sosialisasi }\end{array}$ & \\
\hline 3 & $\begin{array}{l}\text { Yuli } \\
\text { Setyaningrum, } \\
\text { Ani Rosiana, } \\
\text { Ina Yulia } \\
\text { Alfijannah }\end{array}$ & $\begin{array}{l}\text { Hubungan dukungan sosial } \\
\text { dengan kemampuan } \\
\text { sosialisasi anak autisme di } \\
\text { yayasan pondok pesantren } \\
\text { abk al-achsaniyyah kudus } \\
\text { tahun } 2017\end{array}$ & 2017 & $\begin{array}{l}\text { Dukungan } \\
\text { sosial dan } \\
\text { kemampuan } \\
\text { sosialisasi }\end{array}$ & Kudus \\
\hline 4 & $\begin{array}{l}\text { Rana Pratiwi } \\
\text { Rukmana dan } \\
\text { Wiwin } \\
\text { Hendriani }\end{array}$ & $\begin{array}{l}\text { Peran Dukungan Keluarga } \\
\text { dan Konsep Diri Terhadap } \\
\text { Peningkatan Keterampilan } \\
\text { Sosial Anak Tunarungu Di } \\
\text { Sekolah Inklusif }\end{array}$ & 2018 & $\begin{array}{l}\text { Dukungan } \\
\text { keluarga, } \\
\text { Konsep diri } \\
\text { dan } \\
\text { Ketrampulan } \\
\text { sosial } \\
\end{array}$ & Surabaya \\
\hline 5 & $\begin{array}{l}\text { Andini Tiur } \\
\text { Sitompul }\end{array}$ & $\begin{array}{l}\text { Dukungan Sosial Keluarga } \\
\text { Terhadap Kemampuan } \\
\text { Interaksi Sosial Anak Tuna } \\
\text { Daksa di Yayasan Pembinaan } \\
\text { Anak Cacat (YPAC) Medan }\end{array}$ & 2016 & $\begin{array}{l}\text { Dukungan } \\
\text { sosial } \\
\text { keluarga dan } \\
\text { Interaksi } \\
\text { sosial }\end{array}$ & Medan \\
\hline 6 & Roli Sipayung & $\begin{array}{l}\text { Dukungan Sosial Guru dalam } \\
\text { Kemampuan Sosialisasi pada } \\
\text { Anak Retardasi Mental di } \\
\text { Sekolah Luar Biasa Negeri } \\
\text { Binjai }\end{array}$ & 2018 & $\begin{array}{l}\text { Dukungan } \\
\text { sosial guru } \\
\text { dan } \\
\text { Kemampuan } \\
\text { sosialisasi }\end{array}$ & $\begin{array}{c}\text { Sumatera } \\
\text { Utara }\end{array}$ \\
\hline
\end{tabular}

Analisis data : Analisis data yang digunakan adalah analisis data kuantitatif dengan prosentase dan analisis data kualitatif untuk data-data hasil kajian naratif terhadap penelitian-penelitian yang ditemui. Tujuannya adalah untuk melihat apakah variabel dukungan sosial yang diteliti dalam berbagai studi jika dirangkum ke dalam kerangka pikir variabel kemampuan sosialisasi memberikan hasil yang konsisten atau bisa dijadikan dasar untuk menjawab pertanyaan mengenai hubungan dukungan sosial pada kemampuan sosialisasi anak berkebutuhan khusus.

\section{HASIL PENELITIAN}

Berikut studi yang digunakan sebagai sampel penelitian pada kajian meta-analisis. Observasi data pada 6 artikel penelitian dilakukan pada rentang tahun 2015 sampai 2018. Lokasi observasi dari studi-studi tersebut mencakup penelitian di Indonesia. Hasil seleksi terhadap data yang tersedia dapat dilihat pada tabel 1 berupa data-data yang memenuhi syarat untuk meta-analisis. Penelitian-penelitian tersebut diperoleh dari berbagai sumber, baik dari artikel (hasil penelitian) dalam jurnal hasil penelitian maupun laporan penelitian.

\section{Meta Analisis Berdasarkan Tujuan}

Berdasarkan kajian 6 penelitian tersebut di atas analisis meta berdasarkan tujuan masing-masing penelitian dapat dilihat pada taberl berikut :

Tabel 2. Meta Analisis Berdasarkan Tujuan

\begin{tabular}{c|c|c|c}
\hline No & $\begin{array}{c}\text { Tujuan } \\
\text { Penelitian }\end{array}$ & Frekuensi & Prosentase \\
\hline 1. & $\begin{array}{c}\text { Menguji } \\
\text { pengaruh }\end{array}$ & 4 & $60 \%$ \\
\hline 2. & $\begin{array}{c}\text { Mengetahui } \\
\text { hubungan }\end{array}$ & 2 & $40 \%$ \\
\hline
\end{tabular}

Meta Analisis berdasarkan Desain Penelitian Berdasarkan kajian terhadap 6 penelitian tentang hubungan dukungan sosial terhadap kemampuan sosialisasi $\mathrm{ABK}$, maka desain yang digunakan seperti terlihat dalam tabel 3 berikut ini:

Tabel 3. Meta Analisis Berdasarkan Desain Penelitian

\begin{tabular}{c|c|c|c}
\hline No & $\begin{array}{c}\text { Desain } \\
\text { Penelitian }\end{array}$ & Frekuensi & Prosentase \\
\hline 1. & Survei & 4 & $60 \%$ \\
\hline 2. & $\begin{array}{c}\text { Diskriptif } \\
\text { Korelasional }\end{array}$ & 2 & $40 \%$ \\
\hline
\end{tabular}




\section{Meta Analisis Berdasarkan Sumber Data/ Populasi}

Kriteria anak berkebutuhan khusus yang menjadi sumber data dalam penelitian ini meliputi 4 jenis. Yaitu tuna daksa, retradasi mental, anak autism dan anak tuna rungu. Berdasarkan kajian ke -6 penelitian kriteria sumber data bisa dilihat dalam table berikut :

Tabel 4. Meta Analisis Berdasarkan Jenis Sumber Data/ Populasi

\begin{tabular}{c|c|c|c}
\hline No & Jenis Sumber Data & $\begin{array}{c}\text { Frekuen } \\
\text { si }\end{array}$ & $\begin{array}{c}\text { Prosenta } \\
\text { se }\end{array}$ \\
\hline 1. & Tuna daksa & 2 & $30 \%$ \\
\hline 2. & Retradasi mental & 2 & $30 \%$ \\
\hline 3. & Autisme & 1 & $20 \%$ \\
\hline 4. & Tuna rungu & 1 & $20 \%$ \\
\hline
\end{tabular}

\section{Meta Analisi Berdasarkan Metode}

Berdasarkan kajian dari ke enam penelitian tetang hubungan dukungan sosial terhadap kemampuan sosial ABK menunjukkan bahwa semuanya penelitian menggunakan metode diskriptif dengan pendekatan cross sectional. Pendekatan diskriptif adalah penelitian yang digunakan untuk mencari nilai variable mandiri atau lebih independen tanpa membuat perbandingan atau dengan menghubungkan dengan variable lain (Sugiyono ,2012). Meta analisis berdasarkan metode secara lebih jelasnya bisa digambarkan dalam tabal berikut:

Tabel 5. Meta Analisis Berdasarkan Metode

\begin{tabular}{c|c|c|c}
\hline No & $\begin{array}{c}\text { Jenis Sumber } \\
\text { Data }\end{array}$ & Frekuensi & $\begin{array}{c}\text { Prosen } \\
\text { tase }\end{array}$ \\
\hline 1. & $\begin{array}{c}\text { Metode diskriptif } \\
\text { dengan } \\
\text { pendekatan cross } \\
\text { sectional }\end{array}$ & 6 & $100 \%$ \\
\hline
\end{tabular}

\section{Meta Analisis Berdasarkan Analisis Data}

Melalui kajian alisi data ke enam penelitian tersebut di atas, secara jelas dapat digambarkan dalam table 6 berikut ini :

Tabel 6. Meta Analisis Berdasarkan Sistem

\begin{tabular}{|c|c|c|c|}
\hline \multicolumn{4}{|c|}{ Analisis Data } \\
\hline No & $\begin{array}{c}\text { Sistem } \\
\text { Analisis yang } \\
\text { Digunakan }\end{array}$ & Frekuensi & Prosentase \\
\hline 1. & Chi Square & 1 & $20 \%$ \\
\hline 2. & $\begin{array}{c}\text { Uji statistik } \\
\text { korelasi } \\
\text { Kendal } \\
\text { Tau }\end{array}$ & 1 & $20 \%$ \\
\hline 3. & $\begin{array}{c}\text { Analisis } \\
\text { Diskriptif }\end{array}$ & 2 & $30 \%$ \\
\hline 4. & $\begin{array}{l}\text { Analisis } \\
\text { Univariat }\end{array}$ & 2 & $30 \%$ \\
\hline
\end{tabular}

Meta Analisi Berdasarkan Hasil Penelitian

Berdasarkan Meta Analisa hasil kajian ke enam penelitian tentang hubungan dukungan sosial terhadap kemampuan sosialisasi anak berkebutuhan khusus, ditemukan data secara rinci dalam table berikut :

Tabel 7. Meta Analisis Berdasarkan Hasil Penelitian

\begin{tabular}{c|c|c|c}
\hline No & $\begin{array}{c}\text { Hasil Dukungan } \\
\text { Sosial Terhadap } \\
\text { Kemampuan } \\
\text { sosialisasi ABK }\end{array}$ & Frekuensi & $\begin{array}{c}\text { Prosentas } \\
\text { e }\end{array}$ \\
\hline 1. & Ada Hubungan & 6 & $100 \%$ \\
\hline 2. & Tidak ada hubungan & - & $0 \%$ \\
\hline
\end{tabular}

\section{PEMBAHASAN}

Dari kajian terhadap keenam hasil penelitian tentang hubungan dukungan sosial terhadap kemampuan sosialisasi anak berkebutuhan khusus (ABK) khususnya tuna daksa, tuna rungu, autisme dan retardasi mental. Secara umum didapatkan beberapa data bahwa dengan memberikan dukungan sosial dari keluarga, guru maupun orang lain dapat memberikan pengaruh positif terhadap kemampuan bersosialisasi ABK. Dukungan sosial dapat berupa : 1) Dukungan emosional 2) Dukungan penilaian 3) Dukungan informasional 4) dukungan instrumental.

Dari hasil tinjauan kajian dapat diketahui bahwa ABK akan dapat bersosialisasi dengan baik dilingkungannya ketika mendapatkan dukungan sosial yang baik pula. Dukungan sosial dari keluarga dan guru merupakan factor terbesar dalam peningkatan kemampuan bersosialisasi ABK. Dukungan sosial terbesar terletak pada dukungan emosional dan penghargaan.

Akan tetapi dalam penelitian-penelitian tersebut perlu diketahui bahwa dengan berbedanya latarbelakang $\mathrm{ABK}$ akan berbeda pula seberapa besar pengaruh/ hubungan antara dukungan sosial dengan kemampuan bersosialisasi ABK. Dalam penelitian tersebut di atas hanya dibahas ABK dengan latar belakang Tuna daksa, Tuna rungu, Autisme dan retradasi mental saja.

Usia ABK juga akan sangat berpengaruh terhadap hasil hubungan dukungan sosial dengan kemampuan bersosialisasi. Anak usia usia dini 0-6 tahun akan berbeda dangan anak usia 12-18 tahun. 


\section{KESIMPULAN}

Berdasarkan hasil dan pembahasan penelitian, maka dapat disimpulkan bahwa, dukungan sosial baik itu dari keluarga maupun guru dapat berpengaruh terhadap kemampuan sosialisasi anak berkebutuhan khusus.

\section{DAFTAR PUSTAKA}

Dayakisni. (2009). Psikologi Sosial. Malang: UMM press.

Efendi, M (2008), Pengantar psikopedagogik anak berkelaian, Jakarta : Bumi Angkasa

Hallahan, D.P. \& Kauffman, J.M. (2006). Exceptional Learners: Introduction to Special Education 10th ed. USA: Pearson.

Irawan, R (2015). Hubungan Dukungan Keluarga Dengan Kemampuan Sosialisasi Anak Retardasi Mental Ringan Di Slbn 1 Bantul Yogyakarta 2015. Yogyakarta : Jurnal Keperawatan

Nani, D. (2018). Pengaruh dukungan sosial terhadap kemampuan sosialisasi anak berkebutuhan khusus. Jurnal Unsoed.

Poerwanti, E. (2007). Pendidikan Anak Berkebutuhan Khusus. Jakarta.

Pratiwi, L. (2018). Peran Dukungan Keluarga dan Konsep Diri Terhadap Peningkatan Keterampilan Sosial Anak Tunarungu Di Sekolah Inklusif. Philanthrophy Journal of Psychology Vol 2 Nomor 1 (2018), 37-54
Sitompul, A. (2016). Dukungan Sosial Keluarga Terhadap Kemampuan Interaksi Sosial Anak Tuna Daksa di Yayasan Pembinaan Anak Cacat (YPAC) Medan. Medan : Universitas Sumatera Utara press

Spayung, R. (2018). Dukungan Sosial Guru dalam Kemampuan Sosialisasi pada Anak Retardasi Mental di Sekolah Luar Biasa Negeri Binjai. Medan : Universitas Sumatera Utara press

Safarino. (2008). Psikologi dan Jiwa.Retrieved from

Setyaningrum, Y (2017). Hubungan Dukungan Sosial Dengan Kemampuan Sosialisasi Anak Autisme Di Yayasan Pondok Pesantren Abk Al-Achsaniyyah Kudus Tahun 2017. Jurnal Ilmu Keperawatan dan Kebidanan Vol.9 No.1 (2018) 4450.

Sugiyono. (2012). Metode Penelitian Kuantitatif Kualitatif dan $R \& D$. Bandung : Alfabeta

Walinono, H 1999, Pendidikan anak iunagrahila masa sekarang dan akan datang, Yogyakarta : Makalah Seminar Nasional Cacat Mental, 23-25 Maret di SLB/D Pembinaan Yogyakarta 